\title{
The Strategic Plan of University in Facing Challenges of Industrial Revolution 4.0 (Case Study at Universitas Negeri Surabaya)
}

\author{
Nurhasan \\ Universitas Negeri Surabaya \\ nurhasan007@unesa.ac.id \\ Made Pramono \\ Universitas Negeri Surabaya \\ madepramono@unesa.ac.id \\ Martadi \\ Universitas Negeri Surabaya \\ martadi@unesa.ac.id \\ Erta \\ Universitas Negeri Surabaya \\ erta_9@yahoo.com
Hapsari Shinta Citra Puspita Dewi
Universitas Negeri Surabaya
sheenta_999@yahoo.com

\begin{abstract}
Industrial Revolution 4.0, as one of the main paradigms of the modern economy, requires higher education to straighten up to face this trend. Surabaya State University (UNESA) emphasizes the development of human resources $(H R)$ as the main target of internal development in order to deal with industry 4.0. The academic community is encouraged to be sensitive to technology, by increasing intellectual capacity through civilization, training, competition, and / or schools. The study aims to identify the readiness of UNESA in facing challenges of Industrial Revolution 4.0. The implication of this research is to enrich the education management research about linking strategy between higher education and industry demand. The result showed that UNESA had moderate readiness in facing the challenges of Industrial Revolution 4.0 by deepening of intellectual capacity in the IT field through improving campus facilities and infrastructure, and procuring new learning technologies. Networking development with private sector is also becomes useful strategy in linking HR with the IT world related to Industry 4.0. Such a strategic effort under the prevailing laws and regulations enable UNESA to advance in pioneering the development of industry 4.0 on campus, especially for creating qualified graduates.
\end{abstract}

Keywords: Industrial Revolution 4.0, Universitas Negeri Surabaya, Intellectual Capacity, Networking

\section{Article Info}




\section{INTRODUCTION}

The fourth-generation industrial revolution or often referred to as the Industrial Revolution 4.0 raises new challenges for the people, business people, industry and governments of various countries. Information technology which is often referred to as the industrial revolution 4.0 became its own base in human life (Kemristekdikti, 2018:11). McKinsey (2016:14) stated that digital technology towards the industrial revolution 4.0 in the next five (5) years resulted in 52.6 million types of jobs that will have a shift from the world. This research gives the message that everyone who still wants to have a presence in global competition must prepare their mental and skills that have competitive advantages from others. The main way to prepare these skills is by building a behavioural attitude, selfcompetence and a spirit of literacy. The selfpreparation can be nurtured through education (long-life education) and self-concept understanding through having more experience of working across generations / across disciplines (experience is the best teacher).

Education has a very vital role in order to create the next generation of the nation with qualified ability. Education has a very close relationship with human culture and civilization and technological advances that develop over time, especially at the higher education level. Universitas Negeri Surabaya (UNESA) is a university that currently has a very important role in overcoming this human resource development challenges in Indonesian society through education. UNESA, in this case, can be intended as a machine in creating the next generation of the nation to face the future and make this nation have civilization, dignity and be able to compete with other nations in the world. In Industry Revolution 4.0 era, the higher education is required to adapt and become an agent in the process of developing the nation. Preparing graduates who are qualified and able to compete globally, and mastering technological development is important for education stakeholders and the future of a country (Kanematsu \& Barry, 2016). Therefore, the support and role of higher education are expected to increase the competitiveness of the Indonesian people in the global competition of the rapid development of information technology.

UNESA as an institution of higher education that prepares superior graduates in the world of work should be synergized with science and technology in the era of industrial society 4.0. The term Industry 4.0 was born from the idea of a fourth industrial revolution (Prasetyo and Sutopo, 2018: 17). Ślusarczyk (2018: 232) calls this concept of industry 4.0 a new reality in the modern economy with the use of technology and innovation that play an important role in every organization including UNESA. Van Thai and Kim Anh (2017: 1) marks the labour-intensive industries such as clothing and electronics that are most affected with this change. These industries with hundreds or even thousands of workers will be challenged when automation increases. UNESA's policy strategy is important for capturing challenges such as industry 4.0 to be implemented in activities that support the improvement of its human resource competencies inside and outside the UNESA region.

A successful higher education organizations are not only understand existing factors but also predict changes, so they can take advantage of changes in the environment in which they operate (Van Thai and Kim Anh, 2017: 1). The intended change is not a gradual change, but a rapid change which is followed by solving the problems that follow it quickly as well. That is why this challenge is better known as the Industrial Revolution 4.0 as stated by Ślusarczyk (2018:232) above, has changed how humans face the world, and also even changes reality itself. 
A strong base on the Internet of Things and Cyber-Physical Systems that carry, disruptive paradigms such as Factory of the Future, Industry 4.0 is envisioned as an intelligent industrial environment with knowledge in which personalized products are created through intelligent processes and procedures. The fourth industrial revolution will be based on a Physical-Cyber System that will monitor, analyse and automate business processes, transform production and logistics processes into smart factory environments where large data capabilities, cloud services, and smart predictive decision support tools are used to increase productivity and efficiency (Preuveneers and Ilie-Zudor, 2017: 1). The preparation of intelligent personnel through an intelligent process is also an important part of UNESA.

Digital literacy and information for the majority of UNESA users (lecturers and students) from the basic level needs to be provided so that industry 4.0 awareness can actually enter and grow. Therefore, as first step researchers are interested in studied how the role of UNESA readiness in the industrial era 4.0. Researchers direct this interest to the university's strategic policy research in the coordination of LPPM as a form of the integrality of various units in UNESA, especially in terms of research. The main objective of this research is to analyse the input from UNESA users (lecturers, students, education, and the general public) as material for formulating policy recommendations related to industry 4.0.

\section{Extensification and Intensification of IT Field Competencies}

The fourth Industrial Revolution (4 IR) is the stage in the development of knowledge that combine physical, digital and biological spheres (Schwab, 2017:19).Higher education in the fourth industrial revolution is an obscure, rationalistic and energizing open door which can possibly change society to improve things.
The fourth industrial revolution isfuelled by counterfeit consciousness and it will change the work environment from assignments based attributes to the human focused qualities. As a result of the joining of man and machine, it will diminish the subject separation amongst humanities and sociology and in addition science and innovation. For example, there is one restaurant in Surabaya that use 'celebrity robots' which replaced waiters/waitress to serve the customers. This shows that the automation of services lessen the use of human service. Beyond technology lies inequality because the accessibility to technology and connectivity are not equal. Many people are displaced because of lost their jobs, 7 billion world population but only 3.5 billion have access to connectivity (Shahroom \& Hussin, 2018: 316-7).

Mello in Hidayat (2019) mentioned about the three impacts for the higher education as its response to the new technological change brought by Industrial Revolution 4.0:

a. The needs to create a skill improvement and change of working habits of human resource.

b. The elimination of low-level managerial level.

c. The reduction of organization hierarchy as the work will be cooperation or collaboration oriented.

Therefore, it encourage the human resource in each organization, including university to be more self-directed and strive for personality-career outcome. Therefore, in an organizational level, the concept of Resource based View can be implemented and very relevant for organization such as university to face challenges in Industrial Revolution 4.0. The RBV has three dimension such as tangible resource (the physical or infrastructure, financial ability, and technology); intangible resources such as the human resource, innovation and good-will/reputation; and organizational or managerial capabilities such as outstanding organization output, guideline 
for innovation or human resource development, etc. The implementation of e-learning application in certain universities of Indonesia is the perfect example of organizational capabilities.

In the terms of improving human resource quality, the higher education should innovate their training modules, credit and online training development. The flexibledesign of training should be created and meet the profession standard. Furthermore, the higher education could organize the implementation of information technology in course design and course delivery together with the reform of the examination of education. It is important to create mechanism and policy to improve the human resource quality by correlating and building linkage between training and establishment (Piccarrozi et al., 2018).

The industrial revolution 4.0 is the fourth phase of the history of the industrial revolution which began in the 18th century. According to Schwab (2017:34), the world underwent four industrial revolutions. The rapid development of science and technology in the early 20th century has given birth to information technology and production processes that are controlled automatically. Industrial machinery is no longer controlled by human labor but uses a Programmable Logic Controller (PLC) or a computer-based automation system. As a result, production costs are becoming increasingly cheap.

The rapid development of technology in the era of the industrial revolution 4.0 is very influential on the characteristics of jobs that exist today, where skills and competencies are the main things that need attention. Characteristics in the industrial revolution era include digitalization, optimization and customization of production, automation and adaptation, interaction between humans and machines, value added services and business, automatic data exchange and communication, and the use of information technology. Therefore, the world of education and industry must be able to develop industry transformation characteristics by considering the human resource sector that has competence in their fields.

Some authors mention that the educational landscape has been changed by the industrial revolution 4.0, with a variety of implementations (Shahroom and Hussein, 2018: 315; Preuveneers and Ilie-Zudor, 2017: 290; Van Thai and Kim Anh, 2017:3). Industrial Revolution 4.0 is controlled by artificial intelligence and digital physical frameworks that make human-machine interfaces more universal (Shahroom and Hussein, 2018: 315) with further consequences in terms of management and future work through the creation of new business models (Ślusarczyk, 2018: 232). The future projections are still blurred as Industrial Revolution 4.0 in emphasizing the difference between work done by humans and work done by machines.

This obscurity was dramatically revealed by former Finnish Education Secretary Richard Riley about the state of education after 2014: "We are currently preparing students for jobs that do not yet exist, using technologies that have not yet been discovered, to solve problems, which we don't even know are problems" (Liao, et al, 2017: 1). This obscurity, according to researchers, is more directed at the dramatic conceptual irony that departs from the failure to skip important historical stages in the world of technology-economy. Although this irony is exaggerated in describing Industrial Revolution 4.0, this irony is striking in the heart of education. There is a tense atmosphere if the world of education does not have a clear vision of the challenges of Industrial Revolution 4.0, which can be equated as a scientific revolution (Kuhn, 1962:10) which departs from the paradigmatic rage in the face of revolutionary changes in terms of understanding, process, feedback and the futuristic output of science. 
Industrial Revolution 4.0 is implementative "blur". Often, the role of humans in carrying out a revolutionary work is not too distinguishable from the role of machines to make it happen. According to Qin et al (2016: 5) the roadmap for developing technology to realize Industry 4.0 is still not directed. This happens because Industry 4.0 is still in the form of an idea whose actual form from all aspects is unclear so that it can bring up various possible directions for development.

Prasetyo and Sutopo (2018: 24) said that research with aspects of business studies and technology in manufacturing is predicted to be the focus of development direction. The prediction results encourage academics to further enhance cooperation with the manufacturing industry. The pattern of collaboration between academia and industry is very much needed to accelerate the realization of Industry 4.0. The trend of increasing the amount of research each year is proof that academics are beginning to direct their research focus on Industry 4.0. This condition needs to be considered by the education world especially in developing countries so that they are immediately responsive to the changes that occur and prepare their resources in order to deal with Industry 4.0 trends.

The challenge continues with the threat, that the continuation of Industrial Revolution 4.0 threatens the existence of the university. Buildings that make up classrooms are increasingly unsuitable and no longer needed. The pattern of internet networking and artificial intelligence replaces the role of teacher / lecturer, books, and various resources in the presence of students who can study teaching resources from various things. How to teach and how to learn to change. The content taught and the roles of lecturers and students also change (Shahroom and Hussein, 2018: 317). The resistance of the old pattern weakened, replaced by the need for more adaptation to automation thanks to the development of information and communication technology in the world of education.

For this reason, Higher Education is required to formulate strategic policies in various aspects ranging from institutions, fields of study, curriculum, resources, and development of cyber universities, and research to innovation. UNESA as part of higher education institutions must also be swift in analyzing its human resources, one of the main steps that must be done by UNESA is to improve campus data management and information that must be conveyed well for educators and educators as well as to synergize cooperation with developing industries currently. With the existence of a reliable information system will increase competitiveness of competitors and attractiveness to prospective students, by formulating policies derived from the analysis, and acting proactively conceptualized bringing the atmosphere of industry 4.0 in a variety of circumstances and activities. At the paradigmatic level, UNESA needs to get ready for the presence of a new paradigm of learning process that is currently known as Education 4.0 (Shahroom and Hussein, 2018: 317; Halili, 2019:4).

\section{Aligning Industry Requirement with Education}

In order for this to change, higher education must revisit the educational paradigms, and focus on the areas that need rethinking. In today's new world of fast changing technology and information overload, students need to be trained and not taught. Information needs to be made accessible and students need to learn how to find it rather than the teacher offering it to them in a rigid structure.

Furthermore, the students are not alike, do not have the same starting point, can learn and absorb different areas of focus differently and need to be guided to develop their skills rather than taught a set of predefined data 
points. Education 4.0 needs to align with Industry 4.0 and prepare students for the next industrial revolution which will happen in their lifetime. Therefore, it is urgent to bring education into the $21^{\text {st }}$ Century. Flexible, tailormade curricula, taught by teachers who become mentors to their students, and treat them as individuals is the least that today's schools deserve. Giving the workforce of tomorrow the tools to become active lifelong learners can create a diverse and pluralistic society where every person understands and plays to their strengths, building a fair and self-sustaining model for education rather than knowledge.

\section{ALIGNING INDUSTRY REQUIREMENTS WITH EDUCATION}

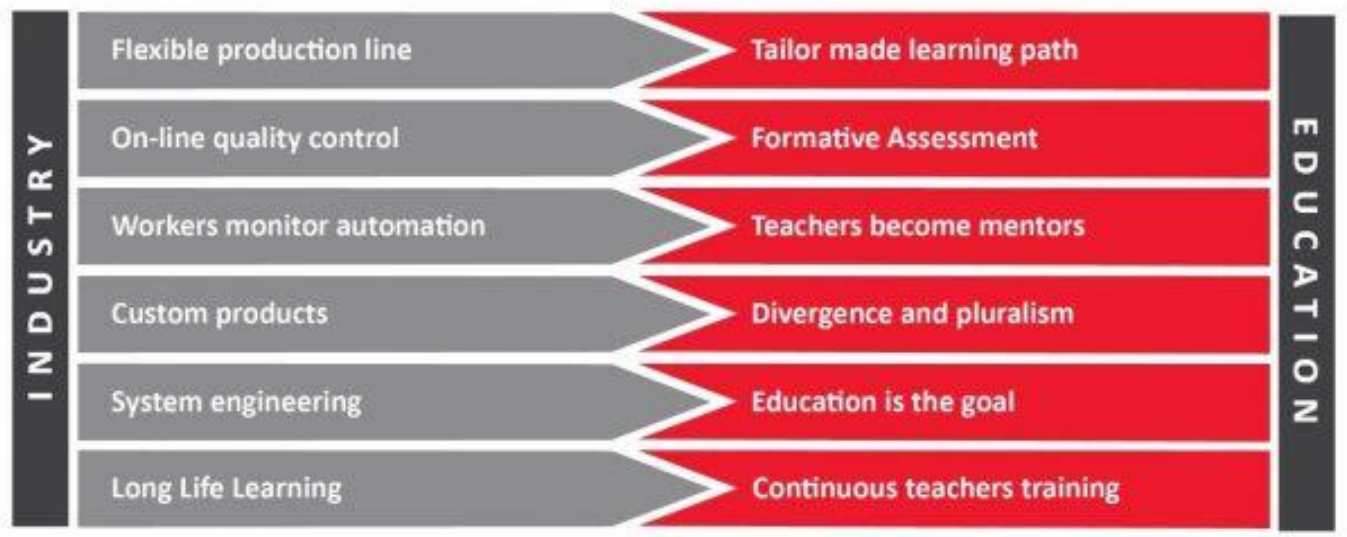

Picture 1. Connecting Industry Requirement with Education

To align industry requirements with education, several changes need to be made. Like having a flexible production line, Education also needs to be flexible and tailormade. Quality control of production needs to be continuous and accessible to all online, while teachers need to have formative assessments on the tools the school uses. On new production lines workers monitor machines and robots and in turn teachers instead of transferring knowledge, become mentors on how to learn.

"Growing with character" as the motto that guides tertiary institutions of UNESA means the process of deepening a person's characteristics to have positive characters that are in line with Indonesian cultural roots from the age of early to adulthood. It can be said like this that is called character education. If referring to nation branding that was proposed by Petra Desatova (2018) with the term "Thailand 4.0", then "UNESA 4.0", UNESA branding is focused oneducating the public with industry 4.0 as a demand for mastering their expertise. Some characteristics of efforts in the context of synergizing education 4.0, industry 4.0 , and growing with character in the form of UNESA 4.0, can be observed as follows.

First, the roots of Indonesian culture are the roots of UNESA's morality, including in facing the industrial era 4.0. Five precepts in the Pancasila as the nation's view of life as well as the philosophy of the Indonesian state became the guiding star of the root of morality.

Secondly, education (in the meaning of lectures) by illuminating the guiding star embodies the implementation of UNESA's preparedness in facing the latest technological developments, in this case industry 4.0. Some paradigmatic changes that must emerge are the role of lecturers to become mentors in training students to be skilled in mastering the Internet of Things andalso Cyber-Physical Systems. Students of the Faculty of Sport Sciences, for example, gain knowledge from diverse sources about sports biomechanics and with that students able to master technology-based data equipment that are interconnected about the ideal shooting size of Indonesian basketball 
athletes. The role of the lecturer is accompanied by the ability to teach how to learn related to the competencies of its students, especially with regard to diverse learning resources.

Third, is the portion of simulation mastery of material in lectures that indicates the potential competency of graduates. For the record, students not only know about how to material, but also understand why or what's for based on a comprehensive and comprehensive understanding.

Finally, the provision of diverse learning resources and learning tools. Visionary projection following the development of industry 4.0 presupposes the growth of laboratories in each faculty. In addition to computer laboratories connected as networks, integrated laboratories in accordance with the competencies to be achieved are also directed to continue to grow. If needed, every student even across study programs and across faculties can practice a theory from the lecture material in an integrated manner in the faculty laboratory. In addition to laboratories, libraries that are developed in line with the latest demands such as digitalization, the presence of robots, and connectivity that continue to develop integrated are also important for the enrichment of differentiated learning resources. Assessment to students in this regard is thus inclusive and open to inputs for change. To identify how UNESA prepare themselves in facing challenges of Industrial Revolution 4.0, the research framework of this study is illustrated below:

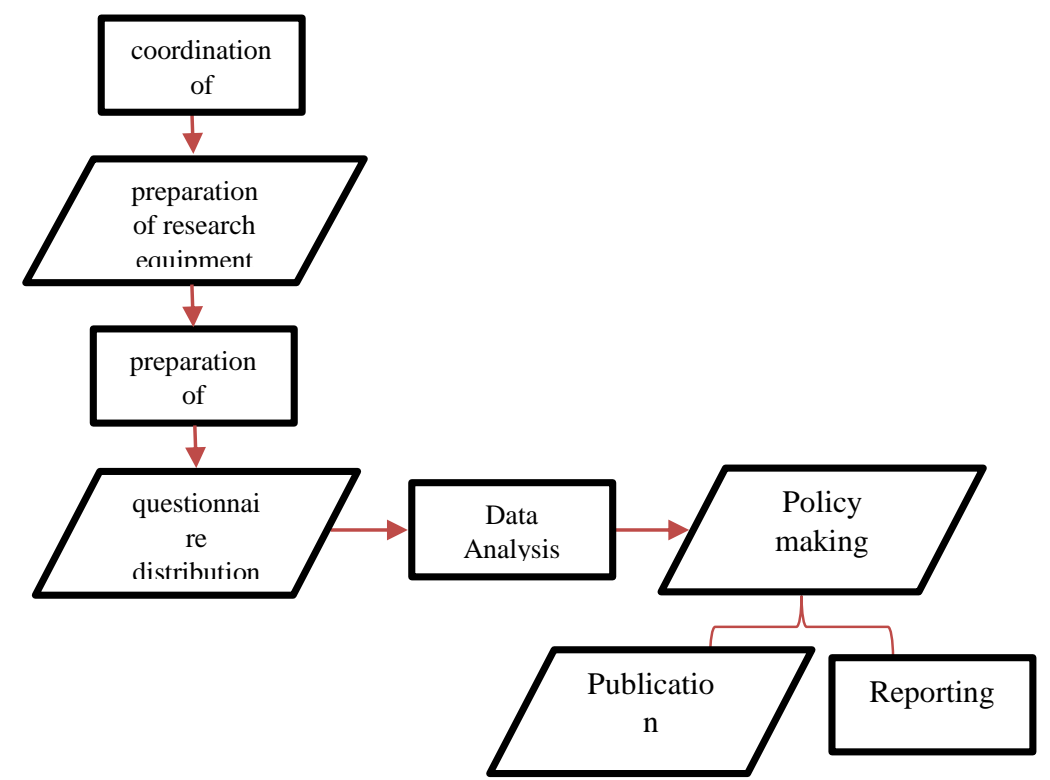

Picture 2. Research Framework

\section{METHODS}

The location in this study is in UNESA, located on the Lidah Wetan and Ketintang campus of Surabaya State University. As policy research, the method used in this research is in the form of the work phase as follows. This work phasing is an implementation interpretation of the implementation of the responsive evaluation model. This evaluation model uses more qualitative data to make policy decisions. The responsive evaluation includes four important aspects: rational, antecedent, transaction and outcome. Rational shows the philosophical background and basic objectives of research namely: how UNESA readiness and strategic plan in facing challenges of Industrial Revolution 4.0. Antecedents, transactions, and outcomes are equivalent to 
inputs, processes, and products. Data is arranged in a description and judgment matrix. To fill in the matrix, the research team can gather considerations from users of the evaluation results. The description of the data is classified into the intent (expected goal) and the observed condition. Judgmental statements are classified in situations that meet the quality standards and specific judgments of program elements. This picture can be seen from the data matrix illustrated in the table below:

Table 1. Data Layout

\begin{tabular}{|c|c|c|c|c|}
\hline & Observasi & & Standard & Judgment \\
\hline \multirow[t]{4}{*}{ RATIONAL } & $\begin{array}{c}\text { Antecedent expected and } \\
\text { implemented }\end{array}$ & Antecedent & $\begin{array}{c}\text { Antecedent } \\
\text { standard }\end{array}$ & $\begin{array}{c}\text { Antecedent } \\
\text { consideration }\end{array}$ \\
\hline & $\begin{array}{l}\text { Expected and implemented } \\
\text { transactions }\end{array}$ & Transaction & $\begin{array}{c}\text { Transaction } \\
\text { standard }\end{array}$ & $\begin{array}{c}\text { Transaction } \\
\text { considerations }\end{array}$ \\
\hline & $\begin{array}{c}\text { Expected and implemented } \\
\text { outcomes }\end{array}$ & Output & Impact standard & Impact consideration \\
\hline & Description matrix & & Jud & t matrix \\
\hline
\end{tabular}

Source: Stufflebeam in Mulyatiningsih (2011:10)

The following table implementation interpretation of the research team in formulating the stages of research implementation. Rational is represented by the analysis phase to identify key concepts which are the result of philosophical thinking about the origin and direction of the destination. Antecedents are also represented in the analysis phase, specifically in terms of resource mapping from UNESA. The design and development stage arises from the results of a review of the transaction. The reporting and publication stage is more output, despite the judgment of the standard and the consideration of the implicit impacts in it.

Tabel 2. The Stage of Research

\begin{tabular}{lll}
\hline \multicolumn{1}{c}{ ANALYSIS STAGE } & \multicolumn{1}{c}{ Information } \\
\hline 1. & \multicolumn{1}{c}{\begin{tabular}{c}
\multicolumn{1}{c}{ Identify new key concepts from various scientific journals and textbooks that } \\
are important for input on how the role of UNESA in the era of RI 4.0
\end{tabular}} & $\begin{array}{l}\text { The research team formulated key } \\
\text { concepts to be developed based on }\end{array}$ \\
2. Mapping the resources of UNESA, which has a role in how UNESA faced & the latest scientific information \\
RI era 4.0 & \\
3. Analysis of other needs, especially regarding the readiness of human & \\
resources, facilities and infrastructure, and existing policies related to RI 4.0
\end{tabular}
DESIGN STAGE Information

1. Design and prepare for development in various important aspects which will The research team at this stage lead to policy recommendations.

2. Updating the data and mapping the resources in UNESA designs data collection and analyzes it as needed.

3. Arrange questionnaire details. Lecturers, education staff, students, and the general public were chosen as respondents.

\section{DEVELOPMENT STAGE}

1. Classify and display the results of data analysis in an integrated manner

2. Develop a recommended policy programto UNESA (Senate and leadership) with reference to the previous stage.

\section{PUBLICATION AND REPORTING STAGE}

1. Writing articles to be sent to the International Journal of Production Research.

2. Publication through international conferences

3. Final reporting.

\section{Information}

The research team presented the results of data analysis and formulated reconditioned policies.

The continuation stage of the results of research development, how research can produce good outcomes. 
Based on the approach, this research is quantitative and qualitative research, because of testing hypotheses, emphasizing the measurement process (quantitative data, calculations) through statistical tests, and focusing on the magnitude of events and relationships between variables; as well as qualitative research, because in explaining the results of statistical testing, the data are also analysed qualitatively (meaning), describe the situation through descriptive analysis, and attach importance to the quality of information. Based on the way the data is collected, this research is survey research, which carried out by taking a portion of the population as a sample or the whole unit in the population to be examined through asking questions to obtain responses or answers from the observed subjects. The data is generated from interviews and questionnaires as data collection instruments. This research is also a qualitative study that uses methods to explore and understand the meaning of a number of samples. This qualitative research process involves important efforts, such as asking questions and procedures, collecting specific data from participants, analysing data inductively starting from specific themes to general themes, and interpreting the meaning of data.

\section{RESULTS AND DISCUSSION}

The Industrial Revolution 4.0, certainly had an impact on the field of education, especially on higher education. Each campus must improve and change the learning paradigm that has been used so far. This millennial era learning is no longer limited by class boundaries but has no limits. The use of digital technology and social media is considered more in line with current learning models. Some things that are considered in the implementation of education in higher education are to provide adequate facilities and infrastructure. Even the things that must be provided by universities are adequate internet access in the campus environment. In the future, tertiary institutions must migrate to ecampus by providing e-laborious, e-services, electronic libraries or e-libraries, online learning or e-learning, online tutors or electurers.

In the outline, there are three main types of fundamental roles in higher education, which is teaching, research, and service.

The role of the College is known as the Tridharma Peguruan Tinggi, which is teaching, research, and community service. How should Surabaya State University position itself in the era of the industrial revolution 4.0? From the illustration above, Surabaya State University must immediately change and adapt to the current era. There are several things that become important points in the transformation of the higher education system, they are: (1) curriculum-oriented in the future, (2) professional teaching staff, (3) initial exposure at work, (4) new agreement on lifelong learning, and (5) openness to educational innovation. The results of the answers of respondents who are acting at the Surabaya State University related to the role of the University in the Industrial Revolution 4.0 era, have a variety of answers including saying UNESA "Preparing graduates to be able to enter the 4.0 era, developing human resources capable of utilizing the industrial revolution 4.0, prioritizing using the Industrial Revolution 4.0 in learning ". There is also another opinion which states that "it still needs to be improved, especially the use of networks between other institutions and universities". Another opinion also said that "It still needs to be improved again by updating Sarpras data, HR training, easy network access in each study program". Other respondents said that "the system at UNESA is too complicated, some have the same contents but still have to input data again 
which require he same data is repeated to input on the existing System Information Management (SIM). Furthermore, the SIM is not connected properly between one and other system. The database cannot automatically enter in several places as explained by interview statement that "Information dissemination on HR needs to improved first, especially to senior teachers". The diverse opinions of the respondents can be concluded that the role of UNESA in the 4.0 Industrial Revolution is very important, so UNESA needs to improve and complete the various aspects needed to support the preparation of the Unity in the 4.0 industrial revolution era in the field of education.

As for the evaluation results related to the readiness of the Surabaya State University in this study generally includes several aspects: 1) digital technology development policies; 2) implementation of digital technology policies; 3) availability of digital technology infrastructure; and 4) human resources readiness in implementing digital technology; 5) data management and security. The five aspects are evaluated through an understanding stage related to the industrial revolution era 4.0 including evaluation of the use of digital technology at UNESA; evaluation of the implementation of digital technology at UNESA; evaluation of human resources at UNESA.

The five aspects of the evaluation are addressed to respondents namely University / Faculty / Institution officials who are active at Surabaya State University. Evaluation at the stage of general knowledge related to the industrial revolution 4.0 on a number of officials at the University / Faculty / Institution of Surabaya State University obtained varying results related to knowledge and understanding, most of them answered already knowing about the industrial revolution 4.0, and understanding related to the industrial revolution 4.0 itself. This can be seen from the answer most of the respondents said that "I already knew, because it became the topic of daily conversation in the environment of government, business and academics".

Meanwhile, there are still respondents who say they do not really understand the relevance of the industrial revolution 4.0. In addition, related to the questions of activities that have been held at UNESA, most of the answers that already existed among the respondents' answers were "general lectures from East Java Deputy Governor, the addition of new subjects, global perspectives on education management, integration of technology. The organizational formulation in courses in the development of educational organizations, blended learning in online-based lectures, MP student journals are based online "; "2016-2017 and 2018 have been carried out, the socialization of what is meant by Industrial Revolution 4.0 and its implementation is in learning". And some also stated that "already, digital literacy courses, applied undergraduate program workshops in the face of RI 4.0 era and video conferencing in learning".

Knowledge Analysis related to the industrial revolution 4.0 which was carried out at Surabaya State University was stated both in general namely the respondents and substantively related to the understanding of the Industrial Revolution 4.0. Higher education can be said to be a centre of innovation in science and technology. But in its implementation, many campuses experience obstacles in commercializing the innovation. The commercialization of newly discovered technology by lecturers or campuses has a significant impact on economic, science \& technology, campus and industry growth in a sustainable manner. Next is an evaluation related to the use of digital technology which includes the orientation of digital technology in UNESA, the benefits of digital technology in UNESA, security related to the network system in UNESA, expectations regarding the 
application of digital technology in UNESA, the ability of facilitators and priority strategies of the 4.0 era in UNESA.

The following is an analysis of the use of digital technology based on the answers of respondents who most respondents gave responses that showed the proportion of respondents who definitely gave a positive appreciation for the use of digital technology. While a small part gives a description of the proportion of respondents who are doubtful or have a negative perception of the use of digital technology in UNESA. Overall, the suitability or readiness for the use of digital technology has not yet reached the established criteria. However, there are 2 (two) aspects that have been fulfilled, namely the respondent's access to all uses of digital technology and the suitability of the work assignments carried This means that most respondents do not question their access to all digital technology applications in UNESA and even tend to be greatly helped by the application of digital technology.

Furthermore, for the evaluation related to the implementation of digital technology policies at the Surabaya State University as a whole from the results of respondents' responses, it shows that the responsiveness is quite appreciative of the implementation of digital technology policies, especially those related to the knowledge and experience they have gained. Otherwise, the suitability of the program with the capability of implementation is quite far below the criteria. This means that there are difficulties for respondents to adjust their ability level with the system applied. Thus it should be noted to the leadership that even though the program is in line with the expectations of the respondents, substantively it still needs to be studied both in terms of material and its development in the process of implementing digital technology programs at UNESA.
In addition to implementing digital technology policy at Surabaya State University, Human Resources also contributed to the process of preparing for the 4.0 industrial revolution. In general, respondents shows good appreciation towards of human resources quality at UNESA in facing the industrial revolution 4.0. The aspect that gets the highest appreciation is the equal treatment of in giving education service. Nevertheless, in the aspects of the interactive approach, has the lowest appreciation. This means that there are still quite a lot of respondents who rate that UNESA's human resource is not all ready to face the industrial era 4.0, so it is necessary to have a leadership role in improving the quality of human resource through various policies going forward.

Among the respondents' answers related to HR was "Preparing graduates to be able to enter the 4.0 era, developing HR capable of utilizing the industrial 4.0 revolution, prioritizing using rev 4.0 in learning". There was also a response from respondents who stated that "there is a need for socialization related to matters relating to the industrial revolution"; "The system at UNESA is too complicated, some have the same contents but still have to input data again. The same data is repeated input on the existing SIM. Not connected properly between 1 and others. The database cannot automatically enter in several places ". The results showed that the components of general knowledge, utilization of digital technology, depictions of the implementation of digital technology, human resources are still have some weaknesses.

\section{CONCLUSION AND RECOMMENDATION}

The results showed that the components of general knowledge, utilization of digital technology, depictions of the implementation of digital technology, HR still showed some weaknesses. Therefore, all of these components 
should be strategically positioned in the face of the Industrial Revolution 4.0 era. The urgency needs of policy regarding various aspects both in terms of Sarana Prasarana, Human Resource, and other aspects that exist in UNESA to better prepare this university in facing challenges of the Industrial Revolution 4.0 .

\section{REFERENCES}

Davy Preuveneers and Elisabeth Ilie-Zudor (2017). The intelligent industry of the future: A survey on emerging trends, research challenges and opportunities in Industry 4.0. Journal of Ambient Intelligence and Smart Environments 00 (20xx) 1-12. DOI 10.3233/AIS170432 .

Desatova, Petra (2018). Thailand 4.0 and the Internal Focus of Nation Branding. Asian Studies Review. DOI: 10.1080/10357823.2018.1512555

Halili, Siti Hajar. (2019). Technological Advancements In Education 4.0. The Online Journal of Distance Education and e-Learning, January 2019 Volume 7 , Issue 1.

Helmawati. (2013). National Education and Optimization of Islamic Board: Active Role of Islamic Board of Education Improving Quality of Education Jakarta: Rineka Cipta, p. 49

Hidayat, Muhammad. (2019). The Entrepreneurship Learning in Industrial 4.0 Era (Case Study in Indonesian College). Journal of Entrepreneurship Education, Vol. 22 (5).

Mulyatiningsih, Endang. (2011). Riset Terapan Bidang Pendidikan dan Teknik. Yogyakarta: UNY Press.

Nasir, M. (2018). Indonesian Higher Education National Policy Facing the Era of the
Industrial Revolution 4.0. Jakarta, March 2018.

Kemristekdikti. (2018). Strategi Kebijakan Kemenristik-DIKTI RI. Retrieved December $\quad 31, \quad 2018$ from<http://www.unp.ac.id/sites/defaul t/files/2018-

09/DIES\%20UNP\%20RAKOR\%20RA PIMPAS\%20LPTK.pdf>

Kuhn, Thomas (1962).The Structure of Scientific Revolutions, Chicago: University of Chicago Press.

Lee, MinHwa., Yun, JinHo Joseph., Pyla, Andreas., Won, DonKyu., Kodama, Fumio., Schiuma, Giovanni., Park, HangSik., Jeon, Jeonghwan., Park, Kyungbae., Jung, KwanHo., Yan, MinRen., Lee, SamYoul and Zhan, Xiaofei. (2018). How to Respond to the Fourth Industrial Revolution, or The Second Information Technology Revolution? Dynamic New Combinantions Between Technology, Market and Society Through Open Innovation. Journal of Open Innovation: Technology, Market and Complexity. Vol. 4 (21), pp 1-24.

Liao, Yongxin. Deschamps, Fernando. Loures, Eduardo de Freitas Rocha \& Ramos, Luiz Felipe Pierin (2017): Past, present and future of Industry 4.0 - a systematic literature review and research agenda proposal, International Journal of Production Research, DOI: 10.1080/00207543.2017.1308576.

McKinsey. (2016).Industry 4.0 After The Initial Hype: Where Manufacturers are finding value and how they can best capture it. Retrieved December 31, 2018 from

http://www.unp.ac.id/sites/default/files/ 2018-

09/DIES\%20UNP\%20RAKOR\%20RA PIMPAS\%20LPTK.pdf> 
Morar, Rabeh \& Arman, Husam. (2017). The Fourth Industrial Revolution 4.0: Social Innovation Perspective. Technology Innovation Management Review, Vol. 7 (1), pp.12-20

Mulyatiningsih, E. (2011). Metode Penelitian Terapan Bidang Pendidikan. Yogyakarta: Alfabeta.

Piccarozzi, Michela., Aquilani, Barbara and Corrado, Gatti. (2018). Industry 4.0 in Management Studies: A Systematic Literature Review. Sustainability, Vol. 10, pp. 1-24.

Presetyo, Hoedi, and Sutopo, Wahyudi (2018). Industry 4.0: Study the Classification of Aspects and Direction of Research Development. Journal of Industrial Engineering, Vol. 13, No. 1, January 2018.

Preuveneers, D., Ilie-Zudor, E, 2017, The Intelligence Industry of the Future: A Survey on Emerging Trends, Research Challenges and Opportunities in Industry 4.0. Journal of Ambient Intelligence and Smart Environments, 9 (3): 287-298.

Sharoom, Aida Aryani and Hussin, Norhayati. (2018). Industrial Revolution 4.0 and Education. International Journal of Academic Research in Business and Social Sciences, Vol. 8 (9), pp. 314-319.

Ślusarczyk, Beata (2018). Industry 4.0- Are We Ready?. Polish Journal of Management Studies. June 2018, Vol.17 No.1.

Schwab, Klaus. (2017). The Fourth Industrial Revolution. Geneva: World Economic Forum.

Thai, H. V., \& Anh, M. A. L.T. K. (2017). The 4.0 Industrial Revolution Affecting
Higher Education Organizations' Operation in Vietnam. International Journal of Management Technology, 4 (2), 1-12

Qin, J., Liu, Y., \& Grosvenor, R. (2016). A Categorical Framework of Manufacturing for Industry 4.0 and Beyond. Procedia CIRP, Vol. 52, pp. 173-178.

Shahroom, A. A., \& Hussin, N. (2018). Industrial Revolution 4.0 and Education. International Journal of Academic Research in Business and Social Sciences, 8(9), 314-319. DOI: 10.6007/IJARBSS/v8-i9/4593

Van Thai, Huynh and Kim Anh, M. A Le Thi (2017). The 4.0 Industrial Revolution Affecting Higher Education Organizations' Operation In Vietnam. International Journal of Management Technology. Vol.4, No 2, pp. 1-12.

Webster, Ray., Andre, John and Giang, Trinh Thi Thu. (2019). Industry 4.0 and Higher Education: Combining Learning Analytics and Learning Science to Transform The Undergraduate Learning Experience in Vietnam. Conference Paper, International Conference: Leadership and Management on Higher Education: Driving Change with Global Trends, pp. 1-12.

\section{Website:}

http://www.intelitek.com/resources/pdf/35$3000-$

0002_WP_Education_4_0_Ver_B.pdf

https://id.wikipedia.org/wiki/Universitas_Nege ri_Surabaya 